\title{
Effects of binders characteristics and concrete dosing parameters on the chloride diffusion coefficient
}

\author{
Daniel V. Ribeiro ${ }^{1 *}$; Silas A. Pinto²; Nilson S. Amorim Júnior²; José S. Andrade Neto³ ${ }^{3}$ Ivan H. \\ L. Santos ${ }^{3}$; Saulo L. Marques ${ }^{3}$; Mavisson J. S. França ${ }^{3}$ \\ *E-mail: verasribeiro@hotmail.com

\footnotetext{
${ }^{1}$ Department of Materials Science and Technology, Federal University of Bahia, Salvador/BA, Brazil.

2 Post-Graduate Program in Civil Engineering (PPEC), Federal University of Bahia, Salvador/BA, Brazil.

${ }^{3}$ Laboratory of Testing on Materials Durability (LEDMa), Federal University of Bahia, Salvador/BA, Brazil.
}

\begin{abstract}
Rebar corrosion in reinforced concrete is one of the most serious manifestations that affect structures, resulting in considerable technical, financial, and social consequences. The corrosive process can be accelerated by carbonation or the action of chlorides, the latter being the phenomenon of greatest concern, since a large part of the world population lives close to a coast. This study analyzed how the characteristics of the cement and the dosing parameters of the concrete influence the diffusion of chlorides in both an isolated and in a combined manner. For this, several concretes were dosed with different water/cement and water/binder ratios, types of cement, mortar content, and mineral additions, each of which had their individual diffusion coefficients obtained from the chloride migration test. It was observed that the water/cement ratio is not the primary parameter for controlling the diffusion of chlorides in concrete. The aluminate content, the fineness of the cement used, and the water/binder ratio, more significantly affect chloride difusión.
\end{abstract}

Keywords: Concrete durability, chlorides in concrete, concrete, cement, dosing parameters, cement binders.

\section{RESUMO}


A corrosão do aço no concreto armado é uma das manifestações mais graves que afetam as estruturas, resultando em consequências técnicas, financeiras e sociais. O processo corrosivo pode ser acelerado pela carbonatação ou pela ação de cloretos, sendo este último o fenômeno de maior preocupação, uma vez que grande parte da população mundial vive próximo ao litoral. Este estudo analisou como as características do cimento e os parâmetros de dosagem do concreto influenciam na difusão dos cloretos de forma isolada e combinada. Para isso, diversos concretos foram dosados com diferentes relações água/cimento e água/ligante, tipos de cimento, teores de argamassa e adições minerais, cada um com seus coeficientes de difusão individuais obtidos no ensaio de migração de cloretos. Observou-se que a relação água/cimento não é o principal parâmetro para o controle da difusão dos cloretos no concreto. $\mathrm{O}$ teor de aluminato, a finura do cimento usado e a relação água/ligante afetam mais significativamente a difusão dos cloretos.

Palavras-chave: Durabilidade de concretos, cloretos, cimento, parâmetros de dosagem, ligantes cimentícios.

\section{RESUMEN}

La corrosión del acero en el hormigón armado es una de las manifestaciones más graves que afectan a las estructuras, con consecuencias técnicas, económicas y sociales. El proceso corrosivo puede acelerarse por carbonatación o por acción de cloruros, siendo este último el fenómeno de mayor preocupación, ya que gran parte de la población mundial vive cerca de la costa. Este estudio analizó cómo las características del cemento y los parámetros de dosificación del hormigón influyen en la difusión de cloruro aislada y combinada. Para ello, se dosificaron varios hormigones con diferentes relaciones agua / cemento y agua / ligante, tipos de cemento, contenidos de mortero y adiciones minerales, cada uno con sus coeficientes de difusión individuales obtenidos en la prueba de migración de cloruros. Se observó que la relación agua / cemento no es el principal parámetro para controlar la difusión de cloruros en el hormigón. El contenido de aluminato, la finura del cemento utilizado y la relación agua / aglutinante afectan de manera más significativa la difusión de cloruros.

Palabras clave: Durabilidad del hormigón, cloruros, cemento, parámetros de dosificación, ligantes cementosos.

\section{INTRODUCTION}

Rebar corrosion is a major cause of premature deterioration of reinforced concrete, leading to significant economic losses (Fei-Long et al., 2014). It is estimated that in developed countries, approximately $40 \%$ of the total resources of the construction industries are applied in repair and maintenance of existing structures (Mehta and Monteiro, 2014). According to the National Association of Corrosion Engineers (NACE, 2020), the global cost of corrosion in 2016, was estimated at US\$ 2.5 trillion, equivalent to 3.4\% of world GDP. In marine regions, the main cause of corrosion in reinforced concrete structures is chloride ion penetration, while the carbonation process is the primary cause in industrial environments and densely populated cities (Cai et al., 2020)

In the absence of chlorides, the passivating film on the rebar is considered stable because the $\mathrm{pH}$ of the solution contained in the pores of the concrete is higher than 11.5. This is commonly observed in Portland cement matrices due to the high levels of alkali and Portlandite (calcium hydroxide) (Zhang et al., 2020). However, in the presence of chlorides, the passive film on the rebar can be destroyed even at $\mathrm{pH}$ values above 11.5. In this case, corrosion does not occur in a generalized way, but in a localized way (pitting corrosion) (Shi et al., 2016). 
The corrosion mechanism is attributed to corrosion cells formed by chlorides that form anodic zones in the pits and the passive film which constitutes the cathodic surface (Munis et al., 2020). The presence of chloride ions in the concrete may be due to seawater, a marine atmosphere, aggregates, accelerating additives containing $\mathrm{CaCl}_{2}$, contaminated water, or industrial pollutants (Balestra et al., 2020). Several aspects influence the likelihood of corrosion by chlorides. A decrease in the water/cement ratio or relative humidity of the concrete, an increase in the covering thickness, the use of mineral additions, or the use of inhibitors reduces the occurrence of corrosion (Das and Pradhan et al., 2020; Harilal et al., 2019)

Recent studies (Andrade Neto et al, 2021; Wang et al., 2018) have evaluated the influence of the addition of fly ash, silica fume, metakaolin, and sugar cane bagasse ash (SCBA) on chloride migration, indicating that the refinement of pores caused by the pozzolanic reaction and the presence of aluminates hindered the diffusion of chlorides through concrete. Malheiro et al. (2021) evaluated the influence of mortar content using the chloride migration test, noting that a decrease in aggregate content and the consequent decrease in transition zones reduces the flow of chlorides in concrete.

Usually, technical standards such as the Brazilian NBR 6118 (ABNT, 2014) and the European EN 206 (EN, 2007), associate the service life of concrete structures with simple parameters such as the water/cement ratio $(\mathrm{w} / \mathrm{c})$. However, the chemical composition of cement, mineral additions, and the distribution of pore sizes, affect the chloride fixation capacity and its ion mobility more significantly (Huang et al., 2019). Nevertheless, these aspects are not addressed by technical standards as being fundamental contributions to improving the durability of concrete. Thus, it is essential that the technical and normative means take these aspects into account, considering their importance through the approach of parameters such as water/binder ratio (w/b - which considers the presence of mineral additions), fineness, and chemical composition of cement.

This study analyzed how the intrinsic characteristics of the raw materials used (aluminate content of cement and additions and specific surface area of cement), the dosing parameters of concrete (water/cement ratio, water/binder ratio, mortar content, and cement content), and its properties in the hardened state (porosity and mechanical strength) influence the diffusion of chlorides in isolated and combined manners. Several concretes were dosed with different water/cement ratios $(\mathrm{w} / \mathrm{c})$, types of cement, percentages of mortar, and mineral additions. These parameters were correlated to their diffusion coefficients in the non-steady state, obtained from the accelerated chloride migration test, which determines the parameters that are most relevant regarding the durability of the concrete to the action of chlorides.

\section{EXPERIMENTAL PROCEDURE}

\subsection{Materials}

In this study, six different types of Portland cement, common in Brazil, were used: CP II-Z 32, CP II-Z 32 RS, CP II-F 32, CP II-E 32, CP IV 32, and CP V ARI RS. Also were used three types of mineral additions (metakaolin, silica fume, and sugarcane bagasse ash), fine quartz aggregate, and coarse aggregate of basaltic origin available in the metropolitan region of Salvador, Bahia (Brazil).

\subsection{Methods}

\subsubsection{Material Characterization}

Table 1 shows the physical characterization and aluminum oxide content of the cements and pozzolanic additions used. The skeletal density was determined using helium gas pycnometry. The particle size distribution was obtained by laser granulometry, the specific surface area measured using a Blaine automatic permeabilizer, and the alumina oxide content by determined with XRF. 
Table 1. Characterization of the cements and pozzolanic additions used to make the proposed mixtures ( $\mathrm{MK}=$ metakaolin; $\mathrm{SF}=$ silica fume; $\mathrm{SCBA}=$ sugar cane bagasse ashes).

\begin{tabular}{|c|c|c|c|c|c|c|c|c|c|}
\hline \multirow[b]{2}{*}{ Properties } & \multicolumn{6}{|c|}{ Brazilian Cements } & \multicolumn{3}{|c|}{ Pozzolanic Additions } \\
\hline & $\begin{array}{c}\text { CP II-E } \\
32\end{array}$ & \begin{tabular}{|c|} 
CP II-F \\
32 \\
\end{tabular} & \begin{tabular}{|c|} 
CP II-Z \\
32 \\
\end{tabular} & $\begin{array}{c}\text { CP II-Z } \\
32 \text { RS }\end{array}$ & $\begin{array}{c}\text { CP IV } \\
32\end{array}$ & $\begin{array}{c}\text { CP V } \\
\text { ARI RS }\end{array}$ & MK & SF & SCBA \\
\hline $\begin{array}{c}\mathrm{Al}_{2} \mathrm{O}_{3} \\
\text { content }(\%)\end{array}$ & $\begin{array}{c}3.78 \pm \\
0.10\end{array}$ & $\begin{array}{c}3.35 \pm \\
0.08\end{array}$ & $\begin{array}{c}4.79 \pm \\
0.12\end{array}$ & $\begin{array}{c}3.42 \pm \\
0.15\end{array}$ & $\begin{array}{c}9.13 \pm \\
0.25\end{array}$ & $\begin{array}{c}4.84 \pm \\
0.09\end{array}$ & $\begin{array}{c}40.54 \pm \\
2.10\end{array}$ & - & $\begin{array}{c}7.56 \pm \\
0.18\end{array}$ \\
\hline $\begin{array}{l}\text { Blaine's } \\
\text { fineness } \\
\left(\mathrm{cm}^{2} / \mathrm{g}\right)\end{array}$ & $\begin{array}{c}4331 \pm \\
35\end{array}$ & $\begin{array}{c}4612 \pm \\
45\end{array}$ & $\begin{array}{c}3297 \pm \\
20\end{array}$ & $\begin{array}{c}2821 \pm \\
31\end{array}$ & $\begin{array}{c}5743 \pm \\
18\end{array}$ & $\begin{array}{c}5115 \pm \\
42\end{array}$ & - & - & - \\
\hline $\mathrm{D}_{50}(\mu \mathrm{m})$ & 19.00 & 2.60 & 23.50 & 50.00 & 4.95 & 37.00 & 17.00 & 4.70 & 36.70 \\
\hline $\begin{array}{c}\text { Sk. density } \\
\left(\mathrm{g} / \mathrm{cm}^{3}\right)\end{array}$ & $\begin{array}{c}3.08 \pm \\
0.02\end{array}$ & $\begin{array}{c}3.15 \pm \\
0.01\end{array}$ & $\begin{array}{c}2.99 \pm \\
0.02\end{array}$ & $\begin{array}{c}3.16 \pm \\
0.01\end{array}$ & $\begin{array}{c}2.84 \pm \\
0.02\end{array}$ & $\begin{array}{c}3.14 \pm \\
0.02\end{array}$ & $\begin{array}{c}2.68 \pm \\
0.01\end{array}$ & $\begin{array}{c}2.35 \pm \\
0.02\end{array}$ & $\begin{array}{c}3.78 \pm \\
0.04\end{array}$ \\
\hline
\end{tabular}

According to Ribeiro et al. (2012), the aluminate content delays the non-steady state diffusion of chlorides, due to the formation of chloroaluminates in the concrete microstructure, especially Friedel's salt $\left(\mathrm{C}_{3} \mathrm{~A} \cdot \mathrm{CaCl}_{2} \cdot 10 \mathrm{H}_{2} \mathrm{O}\right)$.

The physical characteristics of the fine and coarse aggregates used were determined by specific gravity measurements made according to NBR NM 52 (ABNT, 2009) and NBR NM 53 (ABNT, 2009). The particle size distribution was determined by mechanical sieving, according to NBR NM 248 (ABNT, 2003).

Several formulations of concrete were dosed, varying the type of cement, the water/cement ratio (from 0.40 to 0.60 ), the mortar content (54.4 to $100.0 \%$ ), and mineral additions ( 0 to $15 \%$ ). The consumption of materials per cubic meter of concrete and the dosing parameters for the different admixtures used are shown in Table 2.

\subsubsection{Physical-mechanical characterization of concretes}

The concretes used were characterized in terms of apparent porosity, and mechanical strength. After 28 days, three specimens were tested according to NBR 9778 (ABNT, 2009). The compressive strength was carried out according to NBR 5739 (ABNT 2015).

\subsubsection{Chloride Migration Assessment in Concrete}

The test used was based on the UNE 83987 (UNE, 2014) that has been shown to be the most appropriate by using a low voltage $(12 \mathrm{~V})$ and ensuring good conductivity between the electrode and the concrete sample.Through this migration test, it is possible to determine the chloride diffusion coefficient in the non-steady state $\left(D_{n s}\right)$ and steady $\left(D_{s}\right)$ states, in addition to the chloride flow and time lag. The tests were done on four specimens of each series, each with a thickness of $40 \mathrm{~mm}$.

\subsubsection{Statistical analysis}

After determining the correlations between the non-steady-state chloride diffusion coefficients and the characteristics of the materials used, the dosing parameters, and the basic properties of concretes, the determination $\left(\mathrm{R}^{2}\right)$ and correlation $(\mathrm{R})$ coefficients were determined.

The coefficient of determination $\left(\mathrm{R}^{2}\right)$ is a statistical measure of how close the data are to the adjusted regression line, and is also known as the multiple determination coefficient and ranges from 0 (the model has no representativeness of the data) to 1 (the model is fully representative of the data). The correlation coefficient $(\mathrm{R})$ was determined by the Pearson test, in which the correlations can present values ranging from 1 to -1 , with the unit value representing a perfect correlation, either directly $(R=1)$ or inversely $(R=-1)$ proportional, with the results grouped in bands corresponding to negligible $(0.00 \leq \mathrm{R}<0.30)$, low $(0.30 \leq \mathrm{R}<0.50)$, moderate $(0.50 \leq \mathrm{R}<$ $0.70)$, high $(0.70 \leq \mathrm{R}<0.90)$, and very high $(0.90 \leq \mathrm{R} \leq 1.00)$ correlation. 
Table 2. Proportions of materials used and dosing parameters of the produced concrete.

\begin{tabular}{|c|c|c|c|c|c|c|c|c|c|c|c|c|}
\hline \multirow{2}{*}{ Mixture } & \multicolumn{7}{|c|}{ Proportions of materials $\left(\mathrm{kg} / \mathrm{m}^{3}\right)$} & \multirow{2}{*}{$\mathbf{w} / \mathbf{c}$} & \multirow{2}{*}{$\mathbf{w} / \mathbf{b}$} & \multirow{2}{*}{$\begin{array}{c}\text { Brazilian cement } \\
\text { used }\end{array}$} & \multirow{2}{*}{$\begin{array}{c}\text { Total Aluminate } \\
\text { Content }(\%)\end{array}$} & \multirow{2}{*}{$\begin{array}{c}\text { Mortar } \\
\text { Content }(\%)\end{array}$} \\
\hline & Cement & Sand & Gravel & Water & Silica fume & Metakaolin & SCBA & & & & & \\
\hline 1 & 409.6 & 749.5 & 970.6 & 245.7 & - & - & - & \multirow{6}{*}{0.60} & \multirow{3}{*}{0.60} & \multirow{6}{*}{ CP V ARI RS } & 4.48 & 54.42 \\
\hline 2 & 520.8 & 953.1 & 468.7 & 312.5 & - & - & - & & & & 4.48 & 75.87 \\
\hline 3 & 622.5 & 1139.2 & - & 373.5 & - & - & - & & & & 4.48 & 100.00 \\
\hline 4 & 407.6 & 745.9 & 965.9 & 244.5 & 20.5 & - & - & & 0.57 & & 4.27 & 54.86 \\
\hline 5 & 404.1 & 739.5 & 957.6 & 242.4 & 41.0 & - & - & & 0.54 & & 4.07 & 55.28 \\
\hline 6 & 400.7 & 733.2 & 949.5 & 240.4 & 61.4 & - & - & & 0.52 & & 3.88 & 55.70 \\
\hline 7 & 408.0 & 746.7 & 967.0 & 244.8 & - & 20.5 & - & \multirow{3}{*}{0.60} & 0.57 & \multirow{7}{*}{ CP V ARI RS } & 6.20 & 54.86 \\
\hline 8 & 404.9 & 741.0 & 959.7 & 243.0 & - & 41.0 & - & & 0.54 & & 7.79 & 55.28 \\
\hline 9 & 401.9 & 735.5 & 952.5 & 241.1 & - & 61.4 & - & & 0.52 & & 9.26 & 55.70 \\
\hline 10 & 438.9 & 737.4 & 992.0 & 232.6 & - & - & - & \multirow{4}{*}{0.53} & 0.53 & & 4.48 & 54.25 \\
\hline 11 & 436.4 & 733.2 & 986.3 & 231.3 & - & - & 21.8 & & 0.50 & & 4.63 & 54.71 \\
\hline 12 & 433.9 & 729.0 & 980.6 & 230.0 & - & - & 43.4 & & 0.48 & & 4.76 & 55.16 \\
\hline 13 & 431.4 & 724.8 & 975.0 & 228.7 & - & - & 64.7 & & 0.46 & & 4.88 & 55.60 \\
\hline 14 & 537.7 & 806.5 & 699.0 & 268.8 & - & - & - & \multirow{6}{*}{0.50} & \multirow{6}{*}{0.50} & CP II-Z & 4.80 & 65.79 \\
\hline 15 & 542.9 & 814.4 & 705.8 & 271.5 & - & - & - & & & CP II-Z RS & 3.42 & 65.79 \\
\hline 16 & 540.5 & 810.7 & 702.6 & 270.2 & - & - & - & & & CP II-E & 3.78 & 65.79 \\
\hline 17 & 542.6 & 813.9 & 705.4 & 271.3 & - & - & - & & & CP II-F & 3.35 & 65.79 \\
\hline 18 & 532.6 & 798.9 & 692.4 & 266.3 & - & - & - & & & CP IV & 9.13 & 65.79 \\
\hline 19 & 542.9 & 814.4 & 705.8 & 271.5 & - & - & - & & & CP V ARI RS & 2.85 & 65.79 \\
\hline 20 & 568.2 & 852.3 & 738.7 & 227.3 & - & - & - & 0.40 & 0.40 & \multirow{4}{*}{ CP II-Z } & 4.80 & 65.79 \\
\hline 21 & 552.5 & 828.8 & 718.3 & 248.6 & - & - & - & 0.45 & 0.45 & & 4.80 & 65.79 \\
\hline 22 & 537.7 & 806.5 & 699.0 & 268.8 & - & - & - & 0.50 & 0.50 & & 4.80 & 65.79 \\
\hline 23 & 510.2 & 765.3 & 663.3 & 306.1 & - & - & - & 0.60 & 0.60 & & 4.80 & 65.79 \\
\hline
\end{tabular}




\section{RESULTS}

\subsection{Concrete Characterization}

Table 3 shows the values of the diffusion coefficients in the non-steady and steady states, porosity, compressive strength, mortar contents of the concretes, and alumina contents in the binders (\%) and in the concrete $\left(\mathrm{kg} / \mathrm{m}^{3}\right)$. These results will be evaluated to identify which variables are most relevant to the durability of the concrete in isolated and combined manners.

Table 3. Average values of the diffusion coefficients in the non-steady $\left(D_{n s}\right)$ and steady $\left(D_{s}\right)$ states, aluminate percentages in the binder used, and in the concrete, in addition to the porosity of

\begin{tabular}{|c|c|c|c|c|c|c|}
\hline \multirow{2}{*}{ Mixture } & $D_{\text {ns }}$ & $\mathbf{D}_{\mathbf{s}}$ & \multirow{2}{*}{$\begin{array}{c}\mathrm{Al}_{2} \mathrm{O}_{3} \text { content } \\
\text { in the binder } \\
(\%)\end{array}$} & \multirow{2}{*}{$\begin{array}{c}\mathrm{Al}_{2} \mathrm{O}_{3} \\
\text { content in } \\
\text { concrete } \\
\left(\mathrm{kg} / \mathbf{m}^{3}\right)\end{array}$} & \multirow{2}{*}{$\begin{array}{c}\text { Porosity } \\
(\%)\end{array}$} & \multirow{2}{*}{$\begin{array}{c}\text { Compressive } \\
\text { strength } \\
\text { (MPa) }\end{array}$} \\
\hline & \multicolumn{2}{|c|}{$\left(x 1^{-8} \mathrm{~cm}^{2} / \mathrm{s}\right)$} & & & & \\
\hline 1 & $9.22 \pm 0.20$ & $1.46 \pm 0.06$ & 4.48 & 18.35 & $13.78 \pm 0.11$ & $31.00 \pm 1.93$ \\
\hline 2 & $7.52 \pm 0.21$ & $0.76 \pm 0.08$ & 4.48 & 23.33 & $14.02 \pm 0.22$ & $33.00 \pm 1.40$ \\
\hline 3 & $4.74 \pm 0.48$ & $0.96 \pm 0.06$ & 4.48 & 27.89 & $14.54 \pm 0.29$ & $32.65 \pm 2.03$ \\
\hline 4 & $5.88 \pm 0.40$ & $0.94 \pm 0.04$ & 4.26 & 18.26 & $13.09 \pm 0.18$ & $31.35 \pm 1.53$ \\
\hline 5 & $5.06 \pm 0.22$ & $0.98 \pm 0.03$ & 4.07 & 18.10 & $12.51 \pm 0.21$ & $35.44 \pm 0.67$ \\
\hline 6 & $4.21 \pm 0.32$ & $1.00 \pm 0.01$ & 3.89 & 17.95 & $12.13 \pm 0.31$ & $37.67 \pm 0.64$ \\
\hline 7 & $4.97 \pm 0.49$ & $1.26 \pm 0.24$ & 6.20 & 26.58 & $14.42 \pm 0.56$ & $31.95 \pm 1.12$ \\
\hline 8 & $4.30 \pm 0.33$ & $0.82 \pm 0.18$ & 7.79 & 34.78 & $14.14 \pm 0.32$ & $32.80 \pm 3.03$ \\
\hline 9 & $3.07 \pm 0.26$ & $0.54 \pm 0.21$ & 9.26 & 42.91 & $13.71 \pm 0.35$ & $38.85 \pm 0.60$ \\
\hline 10 & $4.42 \pm 0.20$ & $0.99 \pm 0.03$ & 4.48 & 19.66 & $9.27 \pm 0.25$ & $30.62 \pm 0.97$ \\
\hline 11 & $4.13 \pm 0.45$ & $0.98 \pm 0.05$ & 4.63 & 21.20 & $7.96 \pm 0.26$ & $31.76 \pm 2.75$ \\
\hline 12 & $3.60 \pm 0.46$ & $0.81 \pm 0.04$ & 4.76 & 22.72 & $7.45 \pm 0.12$ & $34.16 \pm 3.06$ \\
\hline 13 & $2.77 \pm 0.39$ & $0.50 \pm 0.02$ & 4.88 & 24.22 & $5.89 \pm 0.08$ & $36.99 \pm 0.93$ \\
\hline 14 & $9.32 \pm 0.40$ & $2.40 \pm 0.26$ & 4.80 & 25.79 & $18.03 \pm 0.33$ & $30.37 \pm 1.01$ \\
\hline 15 & $18.55 \pm 0.02$ & $3.56 \pm 0.06$ & 3.42 & 18.55 & $18.00 \pm 0.59$ & $25.11 \pm 1.57$ \\
\hline 16 & $9.45 \pm 0.99$ & $3.81 \pm 0.18$ & 3.78 & 20.45 & $17.32 \pm 0.54$ & $28.15 \pm 2.66$ \\
\hline 17 & $5.31 \pm 0.84$ & $1.53 \pm 0.03$ & 3.35 & 18.19 & $16.80 \pm 0.20$ & $39.73 \pm 3.76$ \\
\hline 18 & $3.23 \pm 0.09$ & $1.69 \pm 0.02$ & 9.13 & 48.64 & $15.83 \pm 0.54$ & $27.04 \pm 2.45$ \\
\hline 19 & $6.06 \pm 0.72$ & $1.52 \pm 0.02$ & 4.85 & 26.33 & $10.91 \pm 0.66$ & $31.83 \pm 3.67$ \\
\hline 20 & $2.77 \pm 0.33$ & $2.50 \pm 0.37$ & 4.80 & 27.26 & $14.42 \pm 0.11$ & $39.10 \pm 0.74$ \\
\hline 21 & $3.21 \pm 0.21$ & $3.16 \pm 0.55$ & 4.80 & 26.50 & $16.45 \pm 0.21$ & $35.52 \pm 1.62$ \\
\hline 22 & $4.70 \pm 0.12$ & $3.77 \pm 0.53$ & 4.80 & 25.79 & $17.18 \pm 0.51$ & $31.45 \pm 1.34$ \\
\hline 23 & $6.74 \pm 0.12$ & $4.27 \pm 0.57$ & 4.80 & 24.48 & $21.00 \pm 0.57$ & $22.66 \pm 0.75$ \\
\hline
\end{tabular}

3.2. Influence of material characteristics, dosing parameters and concrete characteristics on non-steady state chloride diffusion $\left(D_{n s}\right)$

\subsubsection{Analysis of the characteristics of the cement and mineral additions}

Based on the data presented in Table 3, the non-steady state diffusion was correlated with the alumina content $\left(\mathrm{Al}_{2} \mathrm{O}_{3}\right)$ of the binders $(\%)$, in the admixture, per $\mathrm{m}^{3}$ of concrete $\left(\mathrm{kg} / \mathrm{m}^{3}\right)$, and the specific surface area (Blaine) of the ciments, as shown in Figure 1. 


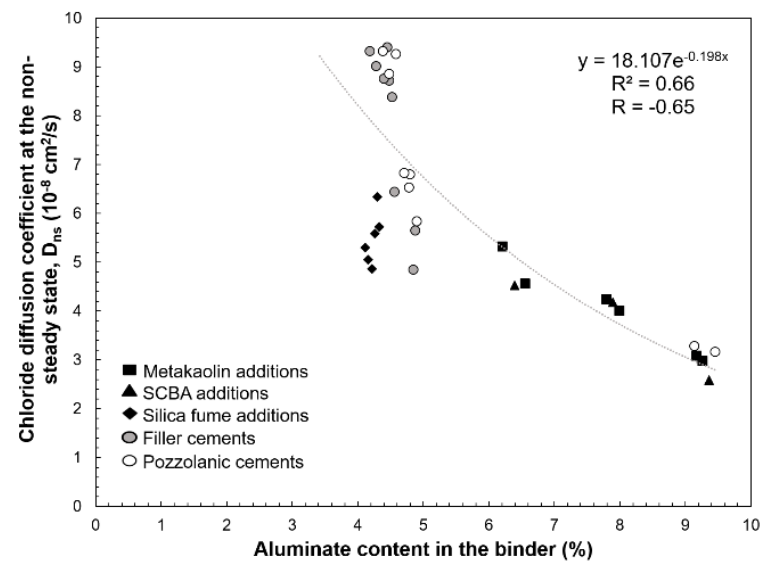

(a)

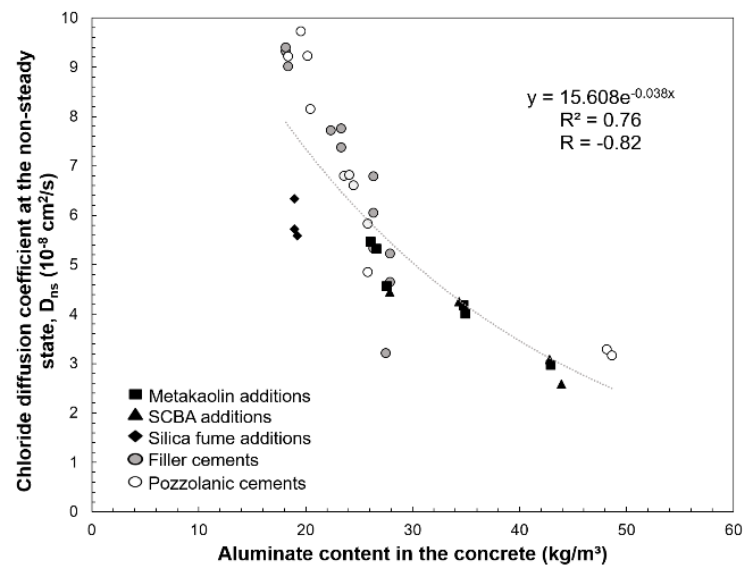

(b)

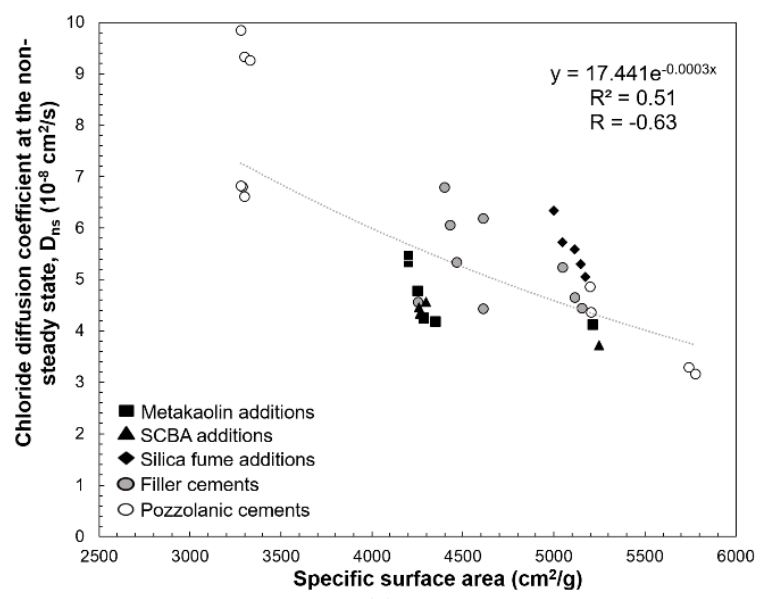

(c)

Figure 1. Correlations between the chloride diffusion coefficient at the non-steady state and (a) aluminate content in the binder $(\%),(b)$ aluminate content in the concrete $\left(\mathrm{kg} / \mathrm{m}^{3}\right)$, and (c) specific surface area of cements.

As apparent, the parameter that showed the highest correlation with non-steady diffusion was the alumina content in the concrete (Figure $1 \mathrm{~b}$ ), with determination coefficients $\left(\mathrm{R}^{2}\right)$ and correlation (R) equal to approximately 0.76 and -0.82 , respectively, indicating a high inverse correlation $(0.70$ $\leq|\mathrm{R}|<0.90)$ between the evaluated data. Despite being less relevant, the alumina content present in the binders (Figure 1a), presented a moderate correlation $(\mathrm{R}=-0.65)$ with non-steady diffusion. Thus, among the parameters associated with the characteristics of cements and pozzolanic additions, it is observed that a high aluminate content in the total concrete mixture is the most important parameter for reducing the non-steady chloride diffusion coefficient, as higher amounts of $\mathrm{Al}_{2} \mathrm{O}_{3}$ of concrete provided greater chloride retention capacity through the greater formation of chloroaluminates (Shi et al., 2012; Shi et al., 2017).

When analyzing the specific surface area of cement, it was observed that there was only a moderate inverse correlation with non-steady state diffusion, with $\mathrm{R}$ approximately equal to -0.63 , thus being considered a secondary parameter of influence on non-steady chloride diffusion in the concrete.

\subsubsection{Analysis of the concrete dosing parameters}

The non-steady diffusion was correlated with the water/cement and water/binder ratio of the concretes, as shown in Figure 2, while Figure 3 shows the correlation of $D_{n s}$ with cement consumption $\left(\mathrm{kg} / \mathrm{m}^{3}\right)$ and with the mortar content $(\%)$ of the concretes.

The water/cement ratio $(\mathrm{w} / \mathrm{c})$ is directly associated with the porosity of cementitious matrices and is used as a dosing parameter, and as a project specification with respect to mechanical strength 
and the durability of structures. However, for modern concretes which use considerable levels of mineral additions to improve their performance, the water/binder ratio has a greater influence on the diffusion of chlorides.

It was observed that the correlation between the chloride diffusion coefficients in the non-steady state $\left(D_{n s}\right)$ and the water/binder ratio $(R=0.78)$ is statistically higher than that observed between $\mathrm{D}_{\mathrm{ns}}$ and the water/cement ratio $(\mathrm{R}=0.54)$. Thus, we should only associate the water/cement ratio with the durability of concretes without mineral additions, because the presence of additions reduces porosity and may increase the availability of aluminates which will reduce diffusivity (increasing durability), even for concretes with the same water/cement ratio (Wang et al., 1997; Rahhal et al., 2014). The results presented in Figures 2a, 2b, and 3a are in agreement with those obtained by Campos et al. (2020), who found that the use of mineral additions promotes better packaging of particles, being more efficient than the consumption of cement or the water/cement ratio $(\mathrm{w} / \mathrm{c})$ in reducing the porosity of the matrices.

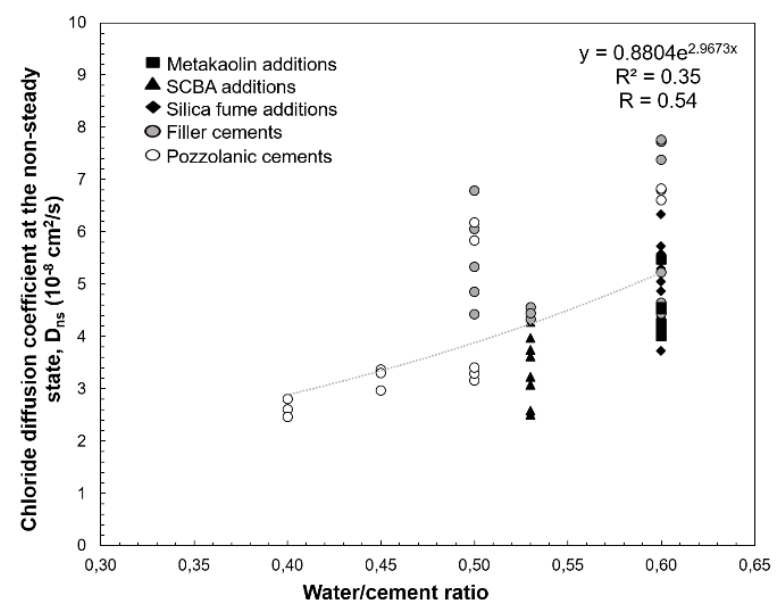

(a)

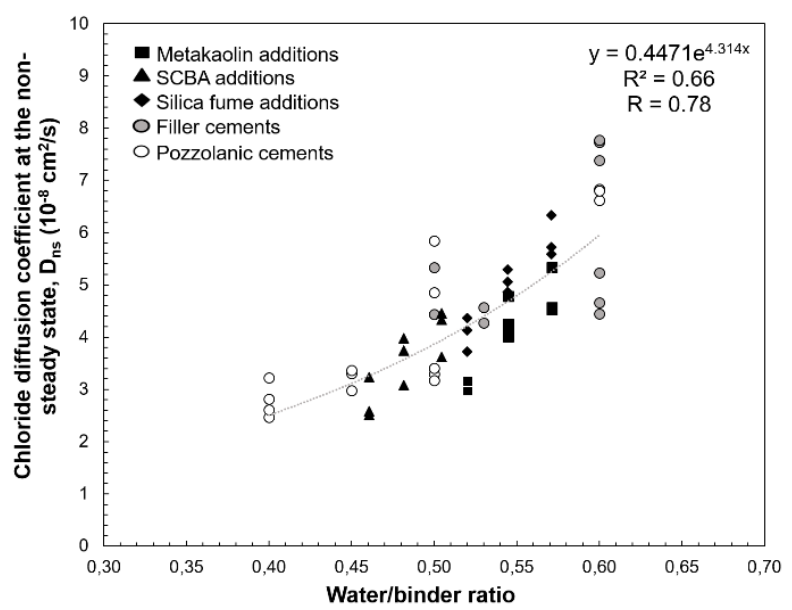

(b)

Figure 2. Correlations between the chloride diffusion coefficient at the non-steady state and the (a) water/cement ratio (w/c), and (b) water/binder ratio of concretes.

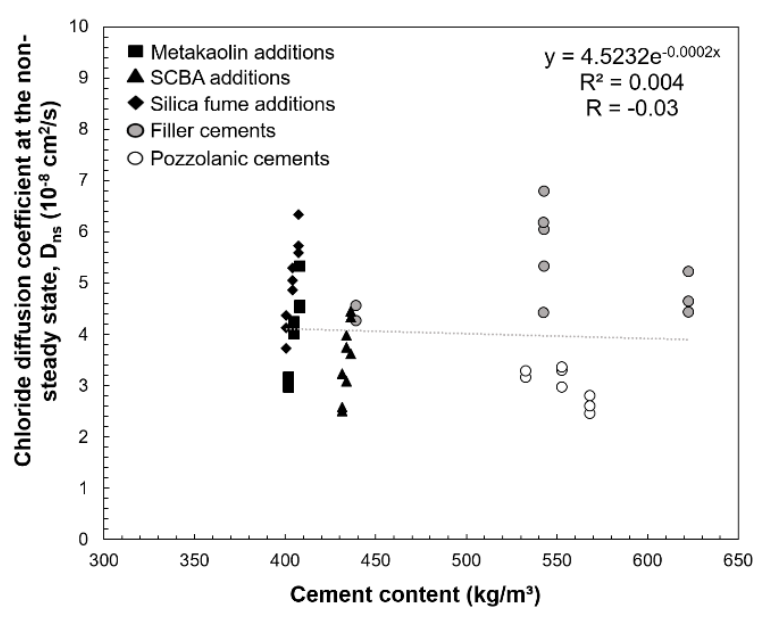

(a)

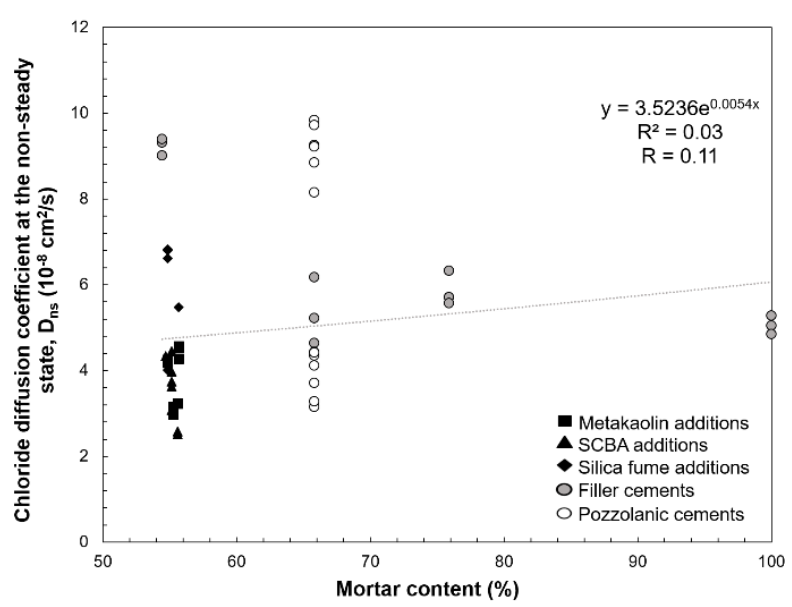

(b)

Figure 3. Correlations between non-steady chloride diffusion coefficient and (a) cement content $\left(\mathrm{kg} / \mathrm{m}^{3}\right)$, and (b) mortar content $(\%)$. 
More specifically, using the equation shown in figure $2 b$, an extremely high resistance to chloride penetration ( $\mathrm{D}<2.5 \times 10^{-12} \mathrm{~m}^{2} / \mathrm{s}$, according to Gjørv (2017)) can be achieved using a water/binder ratio less than 0.40 .

In Figure 3, it is observed that the correlations between the diffusion of chlorides and the cement and mortar content in concrete are negligible $(\mathrm{R}<0.30)$. Evidently, higher cement levels for concretes without additions and with the same characteristics (w/c, type of cement and mortar content) should favor an increase in durability (less diffusivity), owing to the increase in the aluminate content in the mixture, originating from the Portland cement. However, this effect is less significant than the alteration of more representative parameters, mainly the water/cement ratio, which, for concretes without additions, is equal to the water/binder ratio.

The reduction of coarse aggregate/mortar transition zones, as a consequence of a higher mortar content, makes it possible to reduce the flow of chlorides since the main route for diffusion is the transition zone (Malheiro et al., 2011) Alternatively, the cementitious matrix is more porous than the aggregate, increasing diffusion. Thus, no significant correlation was observed between the mortar content and the diffusivity of the concrete (Figure $3 b$ ).

\subsubsection{Characteristics of the hardened concrete}

The non-steady diffusion was correlated with the apparent porosity and compressive strength of the concretes at 28 days (Figure 4). These concrete properties are a consequence of the parameters previously analyzed and are therefore considered response variables.

It is observed that the apparent porosity of the concretes showed a high correlation $(\mathrm{R}=0.75)$ with the non-steady diffusion values. These results converge with those obtained by Zhang and $\mathrm{Li}$ (2011) who found that the porosity of the cementitious matrix is directly related to the diffusion of chlorides into it, being the pore size and its degree of interconnection, preponderant in relation to total porosity. Based on the previous correlations, we can conclude that the water/binder ratio has a greater influence on the porosity of the matrix compared to the water/cement ratio, thus, these factors are essential for the control of durability.

Mechanical strength, being a holistic indicator of the main dosing parameters, also has a reasonable inverse correlation $(\mathrm{R}=-0.68)$ with the diffusivity of the concrete. However, as previously discussed, mechanical strength cannot be the initial parameter for the design of durable concrete, but a natural consequence of these.

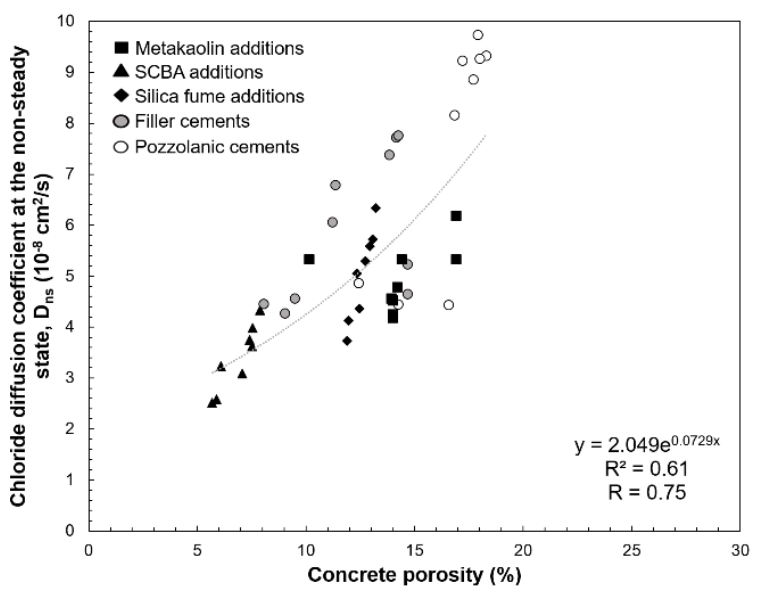

(a)

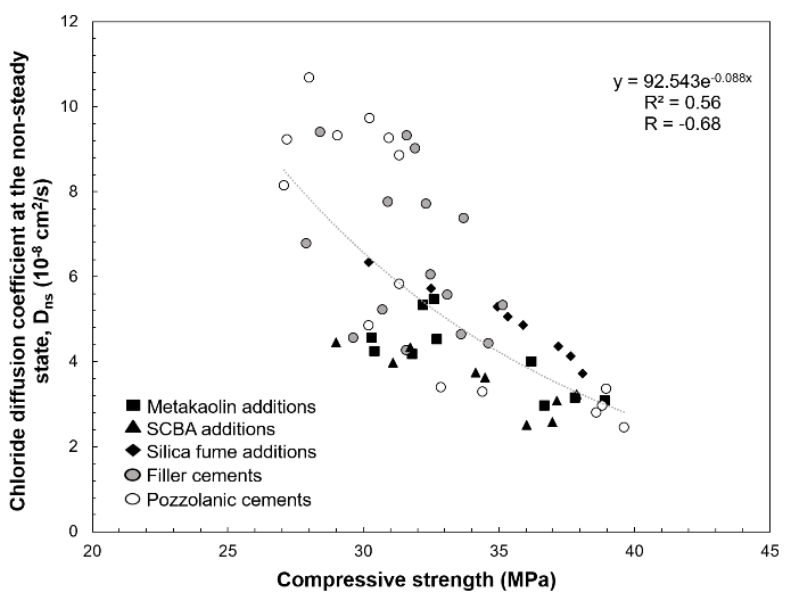

(b)

Figure 4. Correlations between non-steady chloride diffusion coefficient and (a) porosity and (b) compressive strength of the concretes. 
The characteristics of the materials (cements and pozzolans) used, dosing parameters, and concrete properties (at 28 days) regarding the diffusivity of chlorides in the non-steady state $\left(\mathrm{D}_{\mathrm{ns}}\right)$ are classified according to their degree of importance, according to Table 4.

Table 4. Importance level of the characteristics of the materials used (cements and pozzolans), dosing parameters, and concrete properties (at 28 days) regarding the diffusivity of chlorides in non-steady state $\left(\mathrm{D}_{\mathrm{ns}}\right)$.

\begin{tabular}{|c|c|c|c|}
\hline \multirow{2}{*}{ Variables correlated to $\mathbf{D}_{\mathbf{n s}}$} & \multicolumn{3}{|c|}{ Importance Level } \\
\cline { 2 - 4 } & Fundamental & Secondary & Negligible \\
\hline $\begin{array}{c}\text { Characteristics of the } \\
\text { materials used }\end{array}$ & $\begin{array}{c}\mathrm{Al}_{2} \mathrm{O}_{3} \text { content in the } \\
\text { binder and/or concrete }\end{array}$ & $\begin{array}{c}\text { Surface area of } \\
\text { cement }\end{array}$ & --- \\
\hline $\begin{array}{c}\text { Concrete dosing parameters } \\
\text { Water/binder ratio }\end{array}$ & Water/cement ratio & $\begin{array}{c}\text { Cement and mortar } \\
\text { contents }\end{array}$ \\
\hline $\begin{array}{c}\text { Concrete properties }(28 \\
\text { days) }\end{array}$ & Porosity & $\begin{array}{c}\text { Compressive } \\
\text { Strength }\end{array}$ & --- \\
\hline
\end{tabular}

\subsection{Combined analysis of factors involved in the diffusion of chlorides in the non-steady state} $\left(D_{\text {ns }}\right)$ of concrete

\subsubsection{Combined action of aluminate content and concrete porosity on non-steady chloride difusion}

The combined action of the aluminate content $\left(\mathrm{kg} / \mathrm{m}^{3}\right)$ and concrete porosity on the non-steady diffusion of chlorides is represented by the surface shown in Figure 5.

Concretes with alumina contents below $20 \mathrm{~kg} / \mathrm{m}^{3}$ and porosity above $15 \%$ are those that presented critical non-steady state diffusion coefficients, that is, greater than $15 \times 10^{-8} \mathrm{~cm}^{2} / \mathrm{s}$, which, according to Gjørv (2017), classifies these concretes as having low resistance to chloride penetration.

Although this study found that the open porosity of the concrete must be less than $15 \%$, this value cannot be considered a fixed parameter as it does not indicate the distribution of the pore sizes of these concretes. However, it is evident that, depending on the surface formed, non-steady diffusion $\left(D_{n s}\right)$ is governed by both parameters evaluated in a combined manner, be it physical or chemical, and that the higher the total concentration of alumina and the lower the porosity of concrete, it will tend to be a material exhibiting greater durability with reduced action of chlorides.

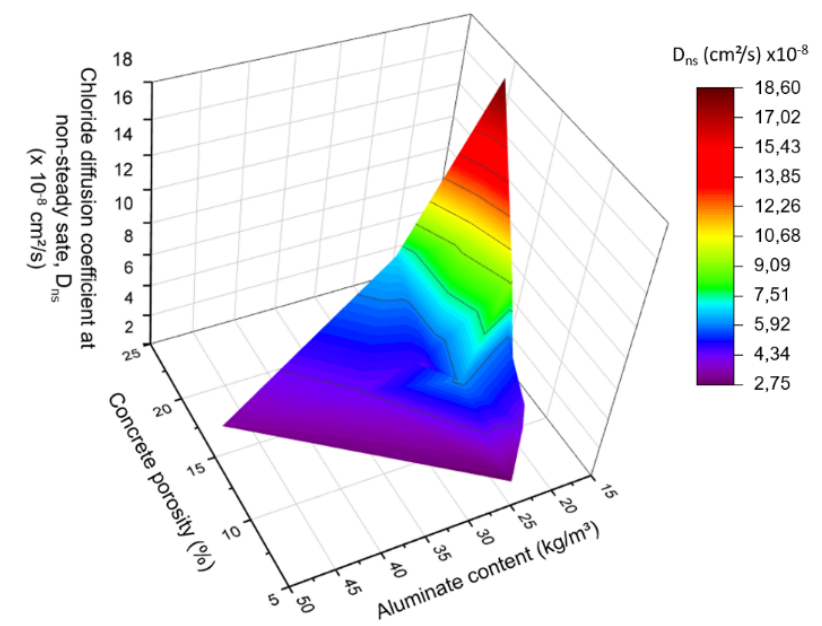

Figure 5. Combined analysis of aluminate content in concrete $\left(\mathrm{kg} / \mathrm{m}^{3}\right)$ and concrete porosity on the non-steady state chloride diffusion coefficient. 
Despite considering the porosity of the concrete as a fundamental parameter in the control of the diffusion of chlorides, there is a more significant variation in the values of non-steady diffusion $\left(D_{n s}\right)$ with the increase in the aluminate content in the mixture. This demonstrates that, although the effect is combined, there is a predominance of the chemical effect on the durability of these matrices, corresponding to the ability to form chloroaluminates.

\subsubsection{Combined action of aluminate content and water/binder ratio in non-steady chloride diffusion}

The combined action of the aluminate content and the water/binder ratio in the non-steady diffusion of chlorides is represented by the surface shown in Figure 6.

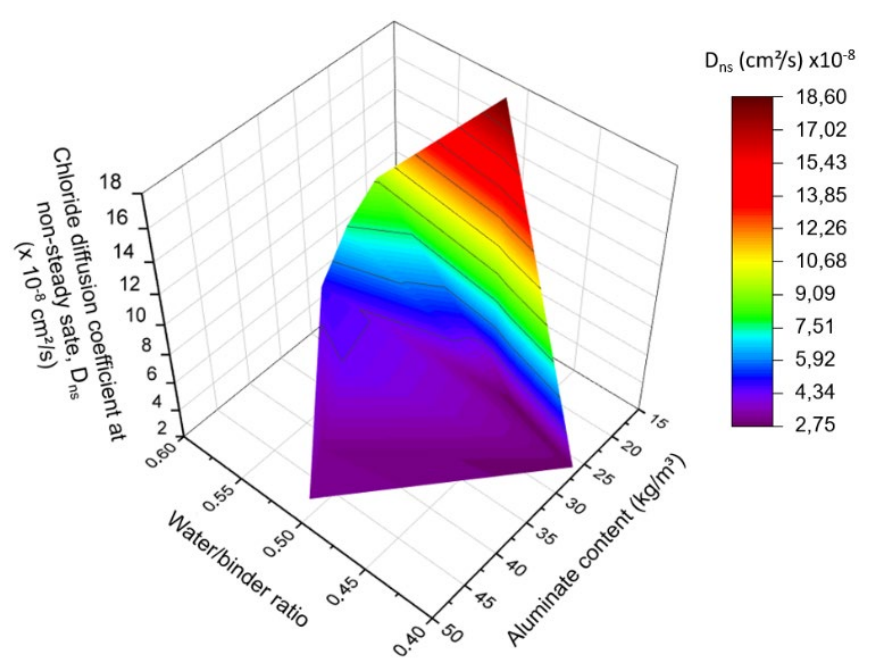

Figure 6. Combined analysis of aluminate content in concrete $\left(\mathrm{kg} / \mathrm{m}^{3}\right)$ and the water/binder ratio on the non-steady state chloride diffusion coefficient.

As seen in the previous item, it is noted that the surface formed is influenced predominantly by the aluminate content $\left(\mathrm{kg} / \mathrm{m}^{3}\right)$ in the matrices studied (chemical effect). Although the water/binder ratio has generated a more significant correlation, when compared to the water/cement ratio, its indiscriminate use may result in errors if adopted as a single parameter for assessing durability. This relationship does not specify the type of mineral addition used and as a result may have chemical and/or physical effects associated with resistance to chloride penetration.

Thus, the aluminate content has a greater association with the water/binder ratio when using additions with high $\mathrm{Al}_{2} \mathrm{O}_{3}$ content, such as metakaolin. However, it is less effective when using additions without the presence of $\mathrm{Al}_{2} \mathrm{O}_{3}$, such as when silica fume is incorporated, reinforcing that the chemical effect is more relevant than the physical effect in the non-steady diffusion of chlorides.

\section{CONCLUSIONS}

From the results presented, it can be concluded that:

- Regarding the characteristics of the materials, the alumina content in the binder and/or in the concrete presented itself as a factor of fundamental importance in the diffusion of chlorides in concrete. The cement fineness is a secondary parameter.

- Regarding the concrete dosing parameters, the water/binder ratio was shown to be a fundamentally important factor in the diffusion of chlorides in concrete. The water/cement ratio is a secondary factor and the consumption of cement and mortar content in the concrete can be considered negligible parameters. According to the results, to achieve an extremely high resistance to chloride penetration, the $\mathrm{w} / \mathrm{b}$ ratio must be less than 0.40 . 
- In consideration of the concrete properties, porosity is a fundamentally important factor in the diffusion of chlorides in concrete, with mechanical resistance being a secondary parameter.

- For an adequate concrete durability design, it should not only consider the dosage parameters generally used, such as water/cement ratio and the cement content, since these parameters alone do not have a good correlation with chloride migration. In the concrete durability design, other parameters such as the aluminates content present in the mixture and water/binder ratio must be considered.

- The parameter that influences the diffusion of chlorides in concrete's cementitious matrices most is the total alumina content $\left(\mathrm{Al}_{2} \mathrm{O}_{3}\right)$, present in both cement and mineral additions, with a minimum combined content of $20 \mathrm{~kg} / \mathrm{m}^{3}$ being recommended.

- The combined analysis of the studied variables indicates that there is a predominance of the chemical effect (aluminate content) in the diffusion of non-steady chlorides, relative to the porosity and the water/binder ratio.

\section{REFERENCES}

Andrade Neto, J. S.; Franca, M. J. S.; Amorim Junior, N. S.; Ribeiro, D.V. (2021), Effects of adding sugarcane bagasse ash on the properties and durability of concrete. Constr. Build. Mater., v. 266, Part A, paper 120959, p. 1-13. 10.1016/j.conbuildmat.2020.120959

Associação Brasileira De Normas Técnicas. (2003). NBR NM 248: Agregados - Determinação da composição granulométrica. Rio de Janeiro.

Associação Brasileira De Normas Técnicas. (2009). NBR 9778: Argamassa e concreto endurecidos - Determinação da absorção de água por imersão - Índice de vazios e massa específica. Rio de Janeiro.

Associação Brasileira De Normas Técnicas. (2009). NBR NM 52: Agregado miúdo-Determinação da massa específica e massa especifica aparente. Rio de Janeiro.

associação brasileira de normas técnicas. (2009). NBR NM 53: Agregado graúdo-Determinação da massa específica, massa específica aparente e absorção de água. Rio de Janeiro.

Associação Brasileira De Normas Técnicas. (2014). NBR 6118: Projeto de estruturas de concreto - Procedimento. Rio de Janeiro.

Associação Brasileira De Normas Técnicas. (2018). NBR 5739: Concreto - Ensaio de compressão de corpos de prova cilíndricos. Rio de Janeiro.

Balestra, C.E.T.; Reichert, T.A.; Pansera, W.A.; Savaris, G. (2020), Evaluation of chloride ion penetration through concrete surface electrical resistivity of field naturally degraded structures present in marine environment. Constr. Build. Mater., v. 230, paper 116979. 10.1016/j.conbuildmat.2019.116979

Cai, Y.; Zhang, W.; Yu, L.; Chen, M.; Yang, C.; François, R.; Yang, K. (2020), Characteristics of the steel-concrete interface and their effect on the corrosion of steel bars in concrete. Constr. Build. Mater., v. 253, paper 119162. 10.1016/j.conbuildmat.2020.119162

Campos, H.F.; Klein, N.S.; Marques Filho, J.; Bianchini, M. (2020), Low-cement high-strength concrete with partial replacement of Portland cement with stone powder and silica fume designed by particle packing optimization. J. Clean. Prod., v. 261, paper 121228, p. 19. $\underline{10.1016 / j . j c l e p r o .2020 .121228}$ 
Das, J. K.; Pradhan, B. (2020), Long term effect of corrosion inhibitor and associated cation type of chloride ions on chloride profile of concrete exposed to composite chloride-sulfate environment. Mater. Today: Proc., v. 32, part 4, p. 803-809. 10.1016/j.matpr.2020.04.014

Fei-Long, F.; Jie, H.; Jiang-Xiong, W.; Qi-Jun, Y.; Zheng-Shan, C. (2014), Corrosion performance of steel reinforcement in simulated concrete pore solutions in the presence of imidazoline quaternary ammonium salt corrosion inhibitor. Constr. Build. Mater., v. 70, p. 43-53. 10.1016/j.conbuildmat.2014.07.082

Gjørv, O. E. (2017), “Durability Design of Concrete Structures in Severe Environments”. Second Edition, CRC Press, p 270.

Harilal, M.; Rathish, V. R.; Anandkumar, B.; George, R. P.; Mohammed, M. S. H. S.; Philip, J.; Amarendra, G. (2019), High performance green concrete (HPGC) with improved strength and chloride ion penetration resistance by synergistic action of fly ash, nanoparticles and corrosion inhibitor. Constr. Build. Mater., v. 198, p. 299-312. 10.1016/j.conbuildmat.2018.11.266

Huang, X.; Hu, S.; Wang, F.; Yang, L.; Rao, M.; Mu, Y.; Wang, C. (2019), The effect of supplementary cementitious materials on the permeability of chloride in steam cured high-ferrite Portland cement concrete. Constr. Build. Mater., v. 197, p. 99-106. 10.1016/j.conbuildmat.2018.11.107

Malheiro, R.; Meira, G.; Lima, M.; Perazzo, N. (2011), Influence of mortar rendering on chloride penetration into concrete structures. Cem. Concr. Compos., v. 33, i. 2, p. 233-239. $\underline{10.1016 / j . c e m c o n c o m p .2010 .11 .003 ~}$

Mehta, P. K.; Monteiro, P. J. M. (2014), “Concrete: Microestructure, properties, and materials”. 4 ed. Mc Graw Hill Education, New York, p. 675.

Munis, A.; Zheng, M.; Zhao, T. (2020), Influence of phosphate ions on pit initiation and growth on the stainless steel $-316 \mathrm{~L}$ in chloride contaminated simulated coal gasification wastewater (CGW) environment. Mater. Chem. Phys., v. 249, paper 123120. 10.1016/j.matchemphys.2020.123120

NACE. (2016). International measures of prevention, application, and economics of corrosion technologies study. Disponível em: < http://impact.nace.org/economic-impact.aspx> Acesso em: 08/012/2020.

Norma Portuguesa. (2007). NP - EN 206: Betão, Parte 1: Especificação, desempenho, produção e conformidade, $84 \mathrm{p}$.

Normalización Española. (2014). UNE 83987: Durabilidad del hormigón. Métodos de ensayo. Determinación de los coeficientes de difusión de los iones cloruro en el hormigón endurecido. Método multirrégimen. Madri.

Rahhal, V.; Talero, R. (2014), Very early age detection of ettringite from pozzolan origin. Constr. Build. Mater., v. 53, p. 674-679. 10.1016/j.conbuildmat.2013.10.082

Ribeiro, D. V., Labrincha, J. A., Morelli, M. R. (2012), Effect of the addition of red mud on the corrosion parameters of reinforced concrete. Cem. Concr. Res., v. 42, i. 1, p. 124-133. 10.1016/j.cemconres.2011.09.002

Shi, J.; Sun, W.; Jiang, J.; Zhang, Y. (2016), Influence of chloride concentration and prepassivation on the pitting corrosion resistance of low-alloy reinforcing steel in simulated concrete pore solution. Constr. Build. Mater., v. 111, p. 805-813. 10.1016/j.conbuildmat.2016.02.107 
Shi, X.; Xie, N.; Fortune, K.; Gong, J. (2012), Durability of steel reinforced concrete in chloride environments: An overview. Constr. Build. Mater. v. 30, p. 125-138. 10.1016/j.conbuildmat.2011.12.038

Shi, Z.; Geiker, M. R.; Lothenbach, B.; Weerdt, K.; Garzón, S. F.; Rasmussen, K. E.; Skibsted, J. (2017), Friedel's salt profiles from thermogravimetric analysis and thermodynamic modelling of Portland cement-based mortars exposed to sodium chloride solution. Cem. Concr. Compos., v. 78, p. 73-83. 10.1016/j.cemconcomp.2017.01.002

Wang, A.; Zhang, C.; Zhang, N. (1997), Study of the influence of the particle size distribution on the properties of cement. Cem. Concr. Res., v. 27, i. 5, p. 685-695. 10.1016/S0008-8846(97)00060$\underline{4}$

Wang, Y.; Shui, Z.; Huang, Y.; Sun, T.; Duan, P. (2018), Properties of coral waste-based mortar incorporating metakaolin: Part II. Chloride migration and binding behaviors. Constr. Build. Mater., v. 174, p. 433-442. 10.1016/j.conbuildmat.2018.04.076

Zhang, D.; Yang, Q.; Mao, M.; Li, J. (2020), Carbonation performance of concrete with fly ash as fine aggregate after stress damage and high temperature exposure. Constr. Build. Mater., v. 242, paper 118125. 10.1016/j.conbuildmat.2020.118125

Zhang, M.; Li, H. (2011), Pore structure and chloride permeability of concrete containing nanoparticles for pavement. Constr. Build. Mater., v. 25, i. 2, p. 608-616. 10.1016/j.conbuildmat.2010.07.032 